\title{
Deparpolisasi Keanggotaan Dewan Perwakilan Daerah (Tela'ah Atas Hasrat Partai Politik Dalam Mengokupasi DPD)
}

\author{
Kiki Wulandari, Putri Apriani, Sulkifly, Irfan Amir \\ Prodi Hukum Tata Negara Fakultas Syari'ah dan Hukum Islam \\ Institut Agama Islam Negeri (IAIN) Bone, Indonesia \\ Email: Kikiwulandari254@gmail.com
}

\begin{abstract}
The beginning of filling the first period of DPD seats (2004-2009) required that the candidate for the DPD members were not an administrator of political parties within a minimum period of four years that calculated until the date of nominating candidates. However, along with the political power struggling in parliament, this requirement then removed in the requirements for the next period of DPD membership. The implication, after being elected as DPD members, the senators forget about their constituent and choose to join certain political parties, the impact of the DPD that they were not focus anymore to fight for the local aspirations of their region, in otherwise they tend to fight for the interests of their political groups/parties. To understand and examine above the problem, the authors conducted normative legal research, with two research approaches namely the statute approach and the conceptual approach. The results showed that the constitutionality of the nomination of DPD members from political parties is the desire of political parties to occupy the DPD which is it cannot be justified, with the following arguments; ( $i$ ) deny the Original Intent of DPD formation, (ii) The concept of bicameralism requires that there are differences in ingredients between the DPR and DPD so that there is no double representation.
\end{abstract}

Keywords : Deparpolisasi; Political Parties; DPD

\begin{abstract}
Abstrak
Dimasa awal pengisian kursi DPD priode pertama (2004-2009) mensyaratkan calon anggota DPD bukan pengurus partai politik dalam rentang waktu minimal empat tahun yang dihitung sampai dengan tanggal pengajuan calon. Namun, seiring dengan pergulatan kekuasaan politik di parlemen, syarat ini kemudian dihilangkan dalam persyaratan pengisian anggota DPD priode berikutnya. Implikasinya, pasca terpilih sebagai anggota DPD, para senator lupa akan konstituennya dan memilih bergabung dengan partai politik tertentu, imbasnya DPD sepenuhnya tidak lagi konsen dalam memperjuangkan aspirasi lokal daerahnya, namun cenderung bertikai untuk memperjuangkan kepentingan kelompok/partai politiknya. Untuk memahami dan menelaah persoalan diatas, penulis melakukan penelitian hukum normatif, dengan dua pendekatan penelitian yaitu pendekatan perundang-undangan (statute approach) dan konspetual (conceptual approach). Hasil penelitian menunjukkan bahwa konstitusionalitas
\end{abstract}


Jurnal Al-Adalah :Jurnal Hukum dan Politik Islam

Vol. 5 No. 1, Januari 2020:52-69

P-ISSN :2406-8802- E-ISSN : 2685-550X

E-mail : aladalah@iain-bone.ac.id

http : /Jurnal.iain-bone.ac.id/index.php/aladalah

pencalonan anggota DPD yang berasal dari partai politik merupakan hasrat partai politik untuk mengokupasi DPD sehingga tidak dapat dibenarkan, dengan argumentasi sebagai berikut; (i) menafikkan Original Intent pembentukan DPD, (ii) Konsep bicameralism mengharuskan ada perbedaan ingredients antara DPR dan DPD sehingga tidak terjadi double representation.

Kata Kunci : Deparpolisasi; Partai Politik; DPD

\section{A. Latar Belakang Masalah}

Berdasarkan logika demokrasi yang bertujuan untuk mewujudkan sistem politik yang demokratis, maka restrukturisasi dan revitalisasi institusi-institusi demokrasi perlu dilakukan. Hal ini urgen, mengingat revitalisasi merupakan langkah progresif dalam mewujudkan proses percepatan demokratisasi yang pada akhirnya bermuara pada perbaikan kesejahteraan rakyat. ${ }^{1}$ Dalam konteks Indonesia, hasil amandemen ketiga UUD NRI 1945 telah melahirkan beberapa lembaga baru yang salah satunya adalah Dewan Perwakilan Daerah (DPD). Hadirnya DPD sebagai salah satu lembaga perwakilan diluar ranah Dewan Perwakilan Rakyat (DPR), diharapkan dapat memainkan peran sebagai lembaga representasi daerah yang mampu memperjuangkan dan mengadvokasi kebijakan pembangunan nasional di pusat agar selaras dengan aspirasi lokal kedaerahan. ${ }^{2}$

Namun pada realitasnya, harapan itu belum mampu di petakan secara baik oleh elit politik di Senayan, entah DPR maupun DPD sendiri. Mereka seolah kehilangan arah akan tanggungjawab yang telah diamanahkan oleh konstituennya masing-masing di lembaga perwakilan. Dampaknya adalah batas antara the first chamber dan the second chamber tidak jelas. Kedua kamar itu seolah sama saja, padahal hakikatnya, mereka jelas harus berbeda. Hal ini urgen, untuk menghindari

\footnotetext{
${ }^{1}$ Masnur Marsuki, “Analisis Kontestasi Kelembagaan DPD Dan Upaya Mengefektifkan Keberadaannya”, Jurnal Ilmu Hukum Vol. 15 No. 1 Januari 2008

${ }^{2}$ Pada masa orde baru khususnya, realitas ketidakadilan dan kurang meratanya pembangunan antara pusat dan daerah menjadi konflik yang cukup mengkhawatirkan. Bahkan di beberapa daerah, marak terjadi pemberontakan untuk melepaskan diri dari Negara Kesatuan Republik Indonesia, seperti Nanggro Aceh Darussalam, Riau, dan Papua. Ancaman disintegrasi atau pemisahan diri tersebutlah yang kemudian memicu keinginan untuk melembagakan aspirasi daerah yang dari awalnya berupa utusan daerah menjadi perwakilan daerah.
} 
double-represantation. ${ }^{3}$ Konsep bicameralism secara eskplisit menjelaskan bahwa tugas DPR sebagai the first chamber adalah untuk menampung aspirasi masyarakat umum, sebab kapasitas mereka di DPR berasal dari representasi politik melalui jalur partai politik (parpol). Tugas the second chamber yang diemban oleh DPD adalah sebagai kamar penyeimbang sekaligus untuk mengakomodir isu-isu daerah tanpa adanya sekat ideologi, komunitas dan sebagainya, sebab anggota DPD sendiri berasal dari representasi wilayah (daerah) yang duduk diparlemen melalui jalur perseorangan non parpol.

DPD sebagai lembaga perwakilan tanpa embel-embel partai politik pada hakikatnya harus terjaga kemurniannya dari pengaruh dan intervensi parpol dan tentunya sangat diharapkan untuk konsen dengan urusan daerah yang semakin kompleks. Bukan terjadi sebaliknya, dimana para senatornya lebih sibuk berafiliasi dengan partai politik tertentu demi perebutan kuasa di DPD. Bobrok internal DPD kemudian mencapai puncaknya dan menjadi sorotan publik tatkala terjadi dualisme kepemimpinan DPD di tahun 2017, yaitu DPD dibawa komando Mohammad Shaleh yang diketahui tidak memiliki dukungan parpol dibelakangnya. Sedangkan satunya lagi adalah pimpinan DPD yang mendapat dukung parpol, yaitu DPD dibawa komando Oesman Sapta Odang (OSO). Background OSO sendiri adalah ketua Partai Hanura yang berhasil mendominasi DPD, yaitu 28 anggota DPD telah berafiliasi menjadi anggota dan kader partai Hanura.

Munculnya dualisme kepemimpinan di DPD, secara kasat mata dapat kita lihat dari data yang dipublikasikan oleh Indonesian Parliementry Center. Hingga akhir 2017, ${ }^{4}$ dominasi kekuatan politik di DPD berada dalam kuasa Partai Hanura, yaitu 28 anggota DPD telah merapat dan menjadi anggota Partai Hanura, sedangkang anggota DPD lainnya yang berafiliasi dengan partai lain, tidak lebih dari sepuluh anggota, kecuali Golkar yang memiliki 14 orang anggota di DPD.

\footnotetext{
${ }^{3}$ Jimly Asshiddiqie, 2017, Konstitusi dan Konstitusioanlisme Indonesia, Sinar Grafikaa, Jakarta Timur, hal. 152.

${ }^{4}$ Ahmad Nurcholis, Katastrofi Dewan Perwakilan Daerah : Parpolisasi, Korupsi dan Kemelut Konflik, Sumber https://ipc.or.id/katastrofi-dewan-perwakilan-daerah-parpolisasikorupsi-dan-kemelut-konflik/, diakses 11 April 2020
} 
Jurnal Al-Adalah :Jurnal Hukum dan Politik Islam

Vol. 5 No. 1, Januari 2020:52-69

P-ISSN :2406-8802- E-ISSN : 2685-550X

E-mail : aladalah@iain-bone.ac.id

http : /Jurnal.iain-bone.ac.id/index.php/aladalah

Untuk partai lainnya, seperti PPP hanya 8 orang, PKS 6 orang, PAN 5 orang, Demokrat dan PKB masing-masing 3 orang, PDI-P dan Partai Aceh masingmasing 2 orang, sedangkan Nasdem, Gerinda, PDS, Partai Buruh, PNI Marhaenisme, PPIB, dan Partai Idaman, masing-masing mempunyai 1orang di DPD.

Dari data tersebut memberikan kita gambaran bahwa setidaknya dari 132 jumlah anggota DPD, 78 senatornya telah berpartai politik, bahkan beberapa diantaranya menjabat sebagai pengurus partai politik. Kondisi ini cukup menghawatirkan bagi perkembangan ketatanegaraan, sebab dengan bergabungnya anggota DPD ke partai politik dapat kita maknai sebagai salah satu bagian dari upaya tersistematis partai politik dalam mengokupasi DPD.

Namun, jawaban kegelisahan atas hasrat okupasi partai politik di DPD tidak berlangsung lama dan menemukan momentumnya ketika Mahkamah Konstitusi sebagai the guardian of constitution memainkan perannya dengan menutup celah terjadinya proses afiliasi anggota DPD dengan partai politik. Melalui Putusan Mahkamah Konstitusi Nomor 30/PUU-XVI/2018, Mahkamah Konstitusi telah menutup peluang bagi fungsionaris/pengurus partai politik untuk maju mencalonkan diri dalam kontestasi pengisian kursi DPD. Selain itu, untuk menjaga kemurnian anggota DPD dari embel-embel partai politik, Mahkamah Konstitusi pula telah menutup peluang bagi senator yang terpilih untuk tidak berpartai politik. ${ }^{5}$

Mendapat angin segar dalam memutus hasrat partai politik untuk mengokupasi DPD, KPU pun bertindak progresif dengan menerbitkan norma baru yang mengatur tentang kewajiban calon anggota DPD untuk mengundurkan diri dari jabatannya jika memegang jabatan sebagai pengurus partai politik. ${ }^{6}$ Namun, aturan ini tidak dihiraukan oleh peserta calon anggota DPD (terutama ketua Partai Hanura, Oesman Sapta Odang), sehingga berdampak pada pencoretan nama

\footnotetext{
${ }^{5}$ Lihat Putusan No. 30/PUU-XVI/2018

${ }^{6}$ Lihat Pasal 60 A ayat 2 PKPU No. 26 Tahun 2018 tentang Perubahan Kedua atas PKPU No. 14 Tahun 2018 tentang Pencalonan Perseorangan Peserta Pemilihan Umum Anggota DPD
} 
Oesman Sapta Odang dalam daftar tetap Calon Perseorangan Peserta Pemilihan Anggota DPD Tahun 2019. ${ }^{7}$

Atas sikap progresif yang diambil oleh KPU, membuat OSO tidak jumawa. Sebagai ketua Partai Politik yang menguasai DPD, OSO enggan untuk tunduk pada putusan Mahkamah Konstitusi yang bersifat final and binding ${ }^{8}$. Dengan dalih pembatasan hak konstitusi, OSO selaku Ketua Umum Partai Hanura sekaligus Ketua DPD melakukan perlawanan terhadap keputusan KPU di Mahkamah Agung dan Pengadilan Tata Usaha Negara. Di Mahkamah Agung, OSO mengajukan uji materiil terhadap Pasal 60A PKPU No. 26 Tahun 2018. Perlawanan OSO, ternyata membuahkan hasil, Mahkamah Agung menyatakan Pasal 60A PKPU No. 26 Tahun 2018 bertentangan Undang-Undang No. 12 Tahun 2011 khususnya Pasal 5 huruf d dan Pasal 6 Ayat 1 huruf I. Begitu pula perlawanan yang ditempuh melalui PTUN, sekali lagi OSO dimenangkan dan Hakim memerintahkan KPU untuk tetap mencantumkan nama OSO di daftar tetap calon anggota DPD.

Berdasarkan ekplikasi a quo di atas, adapun issue hukum yang akan ditela'ah lebih lanjut, adalah Deparpolisasi Keanggotaan Dewan Perwakilan Daerah (Tela'ah Terhadap Hasrat Partai Politik Dalam Mengokupasi DPD). Olehnya itu, untuk menjawab kegelisahan penulis, maka penulis membatasi ruang lingkup pembahasan artikel ini dalam dua batasan masalah yaitu: (1) Bagaimana seharusnya persyaratan keanggotaan DPD dalam peraturan perundang-undangan

7 Pada tanggal 20 September 2019, KPU menerbitkan Keputusan KPU No. 1130/PL.01bag.4-Kpt/06/KPU/IX/2018 tentang penetapan Daftar Calon Perseorangan Peserta Pemilihan Anggota DPD Tahun 2019 dan tidak mencantumkan nama, Oesman Sapta Odang (OSO). Hal ini akibat dari sikap OSO yang tidak mengundurkan diri sebagai ketua Partai Hanura. Oesman Sapta Oddang sebagai salah satu tokoh politik nasional memang kontroversial. Ia memegang jabatan sebagai Wakil Ketua MPR. Selain itu, ia juga menjabat sebagai Ketua Umum Partai Hanura dan berhasil membawa partai Hanura mendominasi DPD (28 anggota DPD merupakan anggota partai Hanura). Alhasil, terjadi konspirasi perebutan kekuasaan sebagai Ketua DPD ditahun 2017 dan berhasil ia menangkan. Pada pemilu serentak 2019, ia memilih maju sebagai calon senator (DPD), bukan sebagai calon anggota DPR.

${ }^{8}$ Sifat final putusan MK berarti tidak adalagi upaya hukum yang dapat ditempuh, sebab Putusan MK telah berkekuatan hukum tetap sejak diucapkan dalam Putusan MK bersifat final artinya, putusan MK langsung memperoleh kekuatan hukum tetap sejak selesai diucapkan dalam sidang pleno terbuka untuk umum. Sifat final ini pula meliputi kekuatan hukum mengikat ( final and binding), yang bermakna tidak hanya mengikat bagi para pihak, namun mengikat seluruh masyarakat Indonesia 
Jurnal Al-Adalah :Jurnal Hukum dan Politik Islam

Vol. 5 No. 1, Januari 2020:52-69

P-ISSN :2406-8802- E-ISSN : 2685-550X

E-mail : aladalah@iain-bone.ac.id

http : /Jurnal.iain-bone.ac.id/index.php/aladalah

dalam memutus hasrat Partai Politik mengokupasi DPD, serta (2) Bagaimana pula kedudukan Putusan Mahkamah Konstitusi No. 30/PUU-XVI/2018 dalam membentengi DPD dari hasrat Partai Politik untuk mengokupasi DPD secara sistematis dan massif.

\section{B. Metode Penelitian}

Dalam mengkaji permasalahan diatas, penulis melakukan studi kepustakaan (library research) dengan menggunakan dua jenis pendekatan penelitian, yaitu pendekatan perundang-undangan (statute approach) dan konseptual (conceptual approach). Penelitian ini digolongkan sebagai penelitian yuridis normatif. Jenis data yang digunakan adalah data kualitatif yang bersumber dari bahan hukum primer dan skunder, seperti UU No. 7 Tahun 2017 tentang Pemilihan Umum, UU No. 12 Tahun 2003 tentang Pemilihan Anggota DPR, DPD, dan DPRD, Putusan MK No. 30/PUU-XVI/201, Putusan Mahkamah Agung Nomor 65 P/HUM/2018. Adapun metode analisa yang digunakan yaitu deskriptif kualitatif yaitu menganalisa data yang diperoleh dari studi kepustakaan terkait Deparpolisasi Keanggotaan DPD (Tela'ah Terhadap Hasrat Partai Politik Dalam Mengokupasi DPD).

\section{Pembahasan}

\section{Konsepsi Persyaratan Anggota DPD}

Dewan perwakilan Daerah sebagai salah satu pelaksana kekuasaan legislatif, merupakan lembaga tinggi negara yang keberadaannya bersifat main constitutional (utama) yang sederajat serta sama dengan DPR. Namun, posisinya hanya berfungsi sebagai co-legislator dibidang legislasi. DPD tidak mempunyai kekuasaan untuk memutuskan atau berperan dalam proses pengambilan keputusan. Padahal jika diperbandingkan dengan DPR, syarat dukungan untuk menjadi senator (anggota DPD) jauh lebih berat daripada persyaratan dukungan untuk menjadi anggota $\mathrm{DPR}^{9}$. Sebab untuk mengikuti kontestasi pemilu legislatif anggota DPR, tidak diperlukan syarat dukungan minimal untuk ditetapkan sebagai

${ }^{9}$ Putu Wawan Suryawan dan I Ketut Rai Setiabudhi, "Sah Tidaknya Anggota Dewan Perwakilan Daerah Masuk Partai Politik”, Program Kekhususan Hukum Tata Negara, Fakultas Hukum, Universitas Udayana, https://ojs.unud.ac.id/index.php/Kerthanegara/article/view/40620, diakses pada hari Jumat, 15 Februari 2019, Pukul 17.20 WITA. 
bakal calon anggota DPR, melainkan harus adanya persetujuan dari partai politik yaitu dengan jalan sebagai anggota Partai Politik Peserta Pemilu (Pasal 240 Ayat 1 Huruf (n) UU No. 7 tahun 2017 tentang Pemilihan Umum). Berbeda dengan DPD, terdapat syarat dukungan minimal yang harus dipenuhi oleh peserta calon anggota DPD.

Pasal 182 UU No. 7 tahun 2017 tentang Pemilihan Umum mensyaratkan bagi calon perseorangan yang ingin menjadi anggota DPD terlebih dahulu harus memenuhi syarat dukungan minimal agar dapat ditetapkan sebagai peserta calon anggota DPD dalam kontestasi pemilu legislatif 2019. Syarat dukungan minimal yang dimaksud harus pula dibuktikan dengan surat atau daftar dukungan yang telah dibubuhi dengan tanda tangan atau cap cempol jari tangan disertai dengan fotokopy KTP setiap pendudukung. Olehnya itu, maka setiap calon anggota DPD setidaknya harus memenuhi syarat dukungan minimal sesuai dengan ketentuan sebagai berikut ; (a) Bagi provinsi dengan jumlah daftar pemilih tetap sampai 1.000.000, maka syarat dukungan minimalnya 1.000 pemilih; (b) Provinsi dengan jumlah penduduk yang termuat dalam daftar pemilih tetap diatas 1.000.0005.000.000, maka syarat dukungan minimal adalah 2.000 pemilih; (c) Provinsi dengan jumlah penduduk yang termuat dalam daftar pemilih tetap diatas 5.000.000-10.000.000, maka syarat dukungan minimalnya adalah 3.000 pemilih; (d) Provinsi dengan jumlah penduduk yang termuat dalam daftar pemilih tetap diatas 10.000.000-15.000.000, maka syarat dukungan minimalnya adalah 4.000 pemilih; (e) Provinsi dengan jumlah penduduk yang termuat dalam daftar pemilih tetap diatas 15.000 .000 , maka syarat dukungan minimalnya adalah 5.000 pemilih. Tidak sampai disitu, syarat dukungan yang dimaksud harus pula tersebar paling sedikit $50 \%$ dari jumlah kabupaten/kota di provinsi yang bersangkutan.

Dengan adanya ketentuan syarat dukungan yang dimaksud tidak terlepas dari hakikat pembentukan DPD. Secara historis, original intent pembentukan DPD adalah sebagai jembatan penghubung antara aspirasi masyarakat lokal daerah dengan pusat, sebagai upaya untuk mengakomodasi kepentingan daerah demi terjaganya integrasi nasional. Pengalaman masa lalu telah memberikan 
Jurnal Al-Adalah :Jurnal Hukum dan Politik Islam

Vol. 5 No. 1, Januari $2020: 52-69$

P-ISSN :2406-8802- E-ISSN : 2685-550X

E-mail : aladalah@iain-bone.ac.id

http : /Jurnal.iain-bone.ac.id/index.php/aladalah

cukup bukti bahwa pola pengambilan kebijakan yang bersifat sentralistik mengakibatkan terjadinya ketimpangan pembangunan, kecemburuan sosial dan rasa ketidakadilan khususnya yang dialami oleh wilayah Indonesia bagian timur, sehingga tidak jarang terjadi konflik yang berujung pada ancaman disintergarsi bangsa $^{10}$. Disamping itu, pembentukan DPD sekaligus mengaminkan rancangan perlemen dua kamar (bikameral) yang mengubah prinsip pengisian lembaga parwakilan Indonesia.

Sebelum DPD terbentuk, prinsip pengisian lembaga perwakilan melalui tiga representasi, yaitu representasi perwakilan politik melalui jalur partai politik, representasi daerah melalui utusan daerah, dan representasi golongan melalui utusan golongan. Kemudian diubah menjadi dua representasi, yaitu representasi politik di DPR melalui jalur partai politik dan representasi wilayah (daerah) di DPD melalui jalur perseorangan non parpol). Dengan prinsip representasi ini, maka jelas bahwa hakikat keanggotaan DPD sebagai representasi daerah dalam sistem perwakilan, yaitu untuk mengakomodasi serta mengadvokasi kepentingan lokal kedaerahan agar terjadi singkronisasi dalam perumusan kebijakan nasional demi terealisasinya pemerataan pembangunan diseluruh wilayah Indonesia.

Secara teoritis, dengan melihat perkembangan politik di Indonesia sejauh ini, maka terdapat beberapa alasan adanya dual representation. Pertama, sebagaimana pendapat dari pakar hukum tata negara, Refly Harun, maka alasan utama adanya dual representation atau bikameral adalah untuk mengakomodir kepentingan yang berbeda, sehingga asal/ingredients kedua kamar ini harus berbeda. Sebab, percuma ada dua kamar ketika ingredients-nya sama saja. Pendapat itu sesuai dengan konsep ideal pengisian anggota DPD periode pertama (2004-2009) yang harus diisi oleh perseorangan dengan salah satu syaratnya tidak pernah menjadi pengurus partai politik dalam rentang waktu minimal 4 tahun

${ }^{10}$ Arifin, Muhammad Zainul. "Suatu Pandangan Tentang Eksistensi Dan Penguatan Dewan Perwakilan Daerah." Jurnal Thengkyang Vol. 1, No. 1 (2019): hal.3 
sampai tanggal pengajuan calon. ${ }^{11}$ Hal ini berarti bahwa bagi mereka yang ingin berkompetisi memperebutkan kursi di DPD seyogyanya adalah mereka yang bukan sebagai pengurus partai politik sekurang-kurangnya 4 tahun, yang dihitung sampai dengan tanggal pengajuan calon. Dengan adanya syarat waktu "minimal 4 tahun sebelum tanggal pengajuan calon anggota DPD" sudah jelas mengindikasikan bahwa sedari awal, pembentukan DPD memang dihindarkan dari kuasa partai politik sebagai konsekuensii logis dianutnya sistem parlemen bicameral, yaitu harus ada pembeda antara kamar pertama dan kamar kedua. .

Namun, seiring dengan pergulatan politik diparlemen mengakibatkan terjadinya deviasi terhadap prinsip "asal/ingredients" dalam sistem bikameral. Deal-deal politik dilembaga perwakilan berhasil mengaburkan prinsip ini dan membuka celah agar DPD dapat diisi oleh orang partai politik. Pasal 182 UU No. 7 Tahun 2017 Tentang Pemilihan Umum, yang mengatur tentang persayaratan calon peserta pemilu anggota DPD seakan meng-copy - paste Pasal 12 UU No. 8 Tahun 2012 Tentang pemilihan DPR, DPD dan DPRD yang tidak membahas sama sekali tentang ketidakbolehan intervensi dari partai politik dikamar DPD.

Pasal 182 UU No. 7 tahun 2017 telah melegitimasi para elit partai politik untuk masuk ke dalam DPD, sebab dari 16 syarat calon anggota DPD yang diatur, tidak satupun ketentuan yang melarang rangkap jabatan sebagai pengurus/anggota parpol dalam rentang waktu minimal 4 tahun sampai tanggal pengajuan calon. ${ }^{12}$ Bahkan di UU MD3 (MPR, DPR, DPD, dan DPRD) sama saja, tidak ada ketentuan yang secara tegas menyatakan bahwa keanggotaan DPD tidak boleh berasal dari partai politik. Pasal 246 UU MD3 hanya menyebutkan bahwa DPD terdiri atas wakil daerah provinsi yang dipilih melalui pemilihan umum. ${ }^{13}$ Berbagai ketentuan yang telah disebutkan, jelas mengindikasikan bahwa kegiatan

${ }^{11}$ Pasal 63 Ayat b UU No. 12 Tahun 2003 Tentang Pemilihan Umum Anggota DPR, DPD dan DPRD, dengan tegas menyebutkan " tidak menjadi pengurus partai politik sekurangkurangnya 4 (empat) tahun yang dihitung sampai dengan tanggal pengajuan calon."

12 Wiwin Suwandi, "OSO yang Jumawa; Peta Jalanan Untuk KPU" https://www.negarahukum.com/hukum/oesman-sapta-odang.html, diakses pada tanggal hari Sabtu, 2 Maret 2019, pukul 10:34 WITA.

${ }^{13}$ Berbeda dengan keanggotaan DPR yang secara tegas dinyatakan terdiri atas anggota partai politik yang dipilih melalui pemilihan umum, lihat UU MD3 No. 14 Tahun 2014, BAB II tetang DPR dan BAB IV tentang DPD. 
Jurnal Al-Adalah :Jurnal Hukum dan Politik Islam

Vol. 5 No. 1, Januari 2020:52-69

P-ISSN :2406-8802- E-ISSN : 2685-550X

E-mail : aladalah@iain-bone.ac.id

http : /Jurnal.iain-bone.ac.id/index.php/aladalah

legislatife dalam membuat UU tentang Pemilihan Umum pada kenyataannya lebih kepada keputusan-keputusan politik praktis yang dapat menguntungkan mereka dan kelompoknya (partainya), bukan atas dasar kepentingan bangsa dan negara. ${ }^{14}$

Kedua, alasan lainnya mengapa DPD harus terbebas dari hegemoni partai politik adalah indikasi akan terjadinya konspirasi dari elit politik ketika mayoritas anggota DPD telah berafiliasi kedalam partai politik yang sama. Sehingga dengan memiliki warna politik yang sama maka akan terbentuk oligarki di DPD. Dan tentunya, oligarki ini terbentuk tidak terlepas dari backup partainya yang dapat menciptakan lahirnya abuse of power.

Kondisi seperti ini, jauh hari telah diperingatkan oleh Lord Acton, dengan ungkapannya yang fenomenal bahwa "Power tends to corrupt, absolute power corrupt absolutely”. Olehnya itu, jika DPD dapat diisi oleh orang partai politik, maka DPD sebagai lembaga penyeimbang DPR yang berperan untuk melakukan sistem check and balances, dikhawatirkan pula akan terseret masuk ke dalam pusaran korupsi politik sehingga dapat menambah daftar senator ${ }^{15}$ yang terjerat kasus korupsi. Berdasarkan data penanganan KPK, sebesar 61,17 persen pelaku yang diproses karena tindak pidana korupsi memiliki latar belakang orang partai politik. Bahkan hasil penulusuran Ismail Aris dkk, menyebutkan bahwa dalam rentang 11 tahun (2007-2018) terdapat 274 politisi yang terjaring kasus korupsi. ${ }^{16}$

Argumentasi akan potensi terjadinya abuse of power dan lahirnya oligarki di DPD telah dibenarkan dengan terjadinya kasus dualisme kepemimpinan DPD priode 2014-2019, yang bermula dari jabatan ketua DPD sebelumnya dijabat oleh Muhammad Saleh kemudian dipolitisasi oleh kelompok tertentu penguasa kursi mayorits DPD, dan jabatannya berhasil "dikudeta” oleh Oesman Sapta Odang melalui perubahan Tatib DPD. Padahal sesuai dengan konvensi ketatanegaraan, seharusnya pimpinan DPD menjabat selama masa waktu 5 (lima) tahun, hal ini

\footnotetext{
${ }^{14}$ Nawawi, Jumriani, Irfan Amir, dan Muljan. "Problematika Gagasan Larangan Mantan Napi Korupsi Menjadi Calon Anggota Legislatif." Al-Adalah: Jurnal Hukum dan Politik Islam 3, no. 2 (2019): hal.152.

${ }^{15}$ Irman Gusman, satu-satunya Anggota DPD yang terjerat korupsi dan ditangkap KPK

${ }^{16}$ Aris, Ismail, Irfan Amir, and Septian Amrianto. "Konstitusionalitas Hak Angket Dewan Perwakilan Rakyat (Dpr) Terhadap Komisi Pemberantasan Korupsi (Kpk)." Al-Adalah: Jurnal Hukum dan Politik Islam 4, no. 2 (2019): hal. 149
} 
sesuai dengan pertimbangan Mahkamah Agung yang menyatakan bahwa masa jabatan pimpinan MPR dan DPR secara eksplisit diatur pada Pasal 24 Jo Pasal 8 Ayat (2) Peraturan MPR RI Nomor 1 Tahun 2014 tentang Tata Tertib yaitu masa jabatan Pimpinan MPR sama dengan masa jabatan keanggotaan MPR adalah 5 tahun. Sedangkan untuk Pimpinan DPR diatur pada Pasal 27 Peraturan DPR RI Nomor 1 Tahun 2014 tentang Tata Tertib, yaitu masa jabatan pimpinan DPR sama dengan masa keanggotaan DPR adalah 5 (lima) tahun.

Dipandang dari karakteristiknya, DPD berada di dalam satu rumpun dengan MPR dan DPR, yaitu sebagai Lembaga Perwakilan, sebagaimana diatur pada UU Nomor 17 Tahun 2014. ${ }^{17}$ Maka merujuk dari aturan ini, sudah jelas bahwa masa jabatan Pimpinan DPD sama dengan masa jabatan anggota DPD. Namun dalam tata tertib DPD yang terbaru, masa jabatan tersebut dipolitisasi dan dipangkas menjadi 2 tahun 6 bulan dan tentunya perubahan ini dapat kita simpulkan sebagai bagian dari konspirasi elit partai politik penguasa DPD. Sebab perubahan tata tertib ini diusulkan dari koalisi partai politik yang menguasai DPD lebih dari lima puluh persen.

Ketiga, analisis lain terkait masalah pencalonan DPD yang harus murni dari non partai politik juga bisa ditarik dari persoalan ambang batas parlemen (parliamentary threshold) yang memiliki kenaikan dari 3,5\% pada tahun 2014 menjadi $4 \%$ pada pemilu serentak 2019. Ambang batas ini diatur di Pasal 414 Ayat (1) UU No. 7 Tahun 2017 tentang Pemilihan Umum, dengan tegas menyatakan bahwa dalam hal penentuan perolehan kursi anggota DPR, maka partai politik yang dapat diikutsertakan dalam penentuan kursi anggota DPR adalah hanya partai politik peserta pemilu yang memenuhi ambang batas parlemen yaitu mendapat perolehan suara minimal $4 \%$ dari jumlah suara sah nasional.

Naiknya Ambang Batas Parlemen, mendorong Lembaga Survey Indonesia (LSI) untuk melakukan survey terkait peluang partai politik untuk lolos ke Senayan, dan hasilnya menunjukkan bahwa setidaknya terdapat enam partai

17 http://www.koran-jakarta.com/jabatan-pimpinan-dpd-tetap-5-tahun/, diakses pada tanggal 4 Maret 2019, Pukul 18.33 WITA. 
Jurnal Al-Adalah :Jurnal Hukum dan Politik Islam

Vol. 5 No. 1, Januari 2020:52-69

P-ISSN :2406-8802- E-ISSN : 2685-550X

E-mail : aladalah@iain-bone.ac.id

http : /Jurnal.iain-bone.ac.id/index.php/aladalah

politik yang terancam tidak diikutsertakan dalam penentuan kursi di DPR, salah satunya adalah partai Hati Nurani Rakyat (Hanura) dibawah besutan OSO. ${ }^{18}$ Artinya, dengan aturan ambang batas ini maka, pada pemilu serentak yang akan dihelat pada tahun 2019, terdapat beberapa partai politik peserta pemilu yang tidak mampu lolos ke DPR. Dan jika ditarik ke dalam masalah pencalonan anggota DPD yang apabila melegalkan pengurus partai politik mencalonkan diri, maupun pada realitas saat ini (anggota DPD Priode 2014-2019) yang begitu dominan masuk partai politik hingga menjadi elit partai politk, maka sudah jelas bagi partai politik yang tereleminasi dari perebutan kursi DPR karena tidak kuasa memenuhi ambang batas $4 \%$, akan tetap eksis dan memberikan pengaruhnya di lembaga perwakilan dengan jalan mengokupasi DPD. ${ }^{19}$

Dari uraian ini kemudian dapat disimpulkan bahwa konsepsi persayaratan calon anggota DPD sebagaimana diatur dalam Pasal 182 UU No. 7 Tahun 2017 terbukti cacat, dengan argumentasi mendegradasi semangat pembentukan DPD sebagai regional representation, sekaligus sebagai the second chamber dalam konsep bicameralism karena tidak memuat secara tegas larangan pencalonan anggota DPD yang berasal dari fungsionaris partai baik sebagai pengurus maupun anggota partai politik sehingga membuka pula kran bagi partai politik yang tidak memenuhi ambang batas parlemen untuk tetap eksis di parlemen dengan jalan mengokupasi DPD.

\section{Kedudukan Putusan Mahkamah Konsitusi No. 30/PUU-XVI/2018}

Ramainya anggota DPD priode 2014-2019 yang tergabung kedalam partai politik dewasa ini terus menjadi perdebatan yang sekiranya menjadi objek perdebatan ketatanegaraan, terlebih pasca keluarnya putusan Mahkamah Konstitusi tentang frasa "pekerjaan lain” dalam Pasal 182 huruf i UU Nomor 7

${ }^{18}$ Keenam partai tersebut yaitu Hanura, PBB, Garuda, PSI, berkarya dan PKPI. Dengan rincian, Hanura : 0,6 persen, PBB : 0,2 Persen, Garuda : 0,2 Persen, PSI : 0,1 Persen, Berkarya : 0,1 Persen, dan PKPI : 0,1 Persen. Bahkan jika ditambahkan dengan angka margin of error, survei ini sebesar 2,6 persen, keenam partai tersebut belum bisa memenuhi ambang batas dan lolos ke DPR.

${ }^{19}$ Mengokupasi DPD atau menduduki DPD dapat dilakukan dengan mengajak anggota DPD masuk menjadi pengurus partai politik, sehingga kepentingan yang diperjuangkan tidak lagi murni aspirasi lokal kedaerahan, namun sesuai dengan arahan dan kepentingan partai politik yang menaunginya seperti yang terjadi terhadap anggota DPD priode 2014-2019. 
Tahun 2017 tentang Pemilihan Umum, yang selanjutnya di ikuti dengan pernyataan, "yang dapat menimbulkan konflik kepentingan dengan tugas, wewenang, dan hak sebagai anggota DPD sesuai dengan ketentuan peraturan perundang-undangan."

Putusan Mahkamah Konstitusi Nomor 30/PUU-XVI/2018, telah memberikan kejelasan bahwa yang dimaksud dari frasa "pekerjaan lain” adalah "pengurus partai politik". Sehingga secara tegas disampaikan dalam pertimbangan hukum putusan;

[3.15] ... Oleh karena itu Mahkamah penting menegaskan bahwa perseorangan warga negara Indonesia yang mencalonkan diri sebagai anggota DPD tidak boleh merangkap sebagai pengurus partai politik sehingga Pasal 182 huruf i UU Pemilu harus dimaknai sebagaimana tertuang dalam amar Putusan ini. ${ }^{20}$

Berdasarkan putusan Mahkamah Konstitusi di atas, secara tegas yang dilarang untuk maju dan mencalonkan diri menjadi anggota DPD adalah pengurus atau fungsionaris partai yang memiliki jabatan, tugas, fungsi dan tanggungjawab kepengurusan di partai politik, yang dipastikan dapat menimbulkan konflik kepentingan dengan tugas dan wewenang anggota DPD sebagai representasi masyarakat lokal. Persoalannya adalah, ada ruang kosong yang debatable dalam putusan ini terkait dengan waktu berlakunya, Mahkamah Konstitusi membiarkan publik untuk menafsirkan sendiri terkait waktu berlakunya putusan ini. Maka dari itu, ketika Pasal 60 A PKPU No. 26 Tahun 2018 tentang Perubahan Kedua atas PKPU No. 14 Tahun 2018 tentang Pencalonan Perseorangan Peserta Pemilihan Umum Anggota DPD di ajukan kepada Mahkamah Agung (MA) untuk dilakukan uji materiil, hasilnya adalah MA menyatakan Pasal 60 A PKPU No. 26 Tahun 2018 tetap mempunyai kekuatan hukum mengikat dan berlaku umum sepanjang tidak diberlakukan surat terhadap peserta pemilu DPD tahun $2009 .^{21}$

${ }^{20}$ Lihat Pertimbangan Hukum Nomor 3.15, 3.16 dan 3.17 dalam Putusan Mahkamah Konstitusi Nomor 30/PUU-XVI/2018, hal. 48-51

${ }^{21}$ Secara tegas pada konsideran mengadili : [3] Menyatakan Ketentuan Pasal 60A Peraturan KPU Nomor 26 Tahun 2018 Tentang Perubahan Kedua Atas Peraturan KPU Nomor 14 
Jurnal Al-Adalah :Jurnal Hukum dan Politik Islam

Vol. 5 No. 1, Januari 2020:52-69

P-ISSN :2406-8802- E-ISSN : 2685-550X

E-mail : aladalah@iain-bone.ac.id

http : /Jurnal.iain-bone.ac.id/index.php/aladalah

Dari pertimbangannya, jelas Mahkamah Agung mengedepankan penggunaan asas non retroactive atau tidak boleh berlaku surut dalam memandang putusan Mahkamah Konstitusi. Namun, pertimbangan ini dapat dibantah dengan beberapa argument. Pertama, jika ditilik kebelakang, terdapat beberapa putusan Mahkamah Konstitusi yang menggunakan asas retroactive, diantaranya adalah Putusan Mahkamah Konstitusi yang keluar dua hari sebelum hari pencoblosan Pilpres 2009 yang inti putusannya membolehkan penggunaan KTP dan KK bagi warga yang belum terdaftar di DPT untuk menggunakan hak pilihnya dalam Pemilihan Presiden 2009. ${ }^{22}$ Putusan lain adalah putusan PUU No. 10 Tahun 2008 tentang Pemilu Anggota DPR, DPD dan DPRD. Pengujian Pasal 205 Ayat (4), Pasal 211 dan Pasal 212 UU a quo. Demikian pula dalam pengujian UU No. 39 Tahun 1999 Tentang Hak Asasi Manusia (kasus Bom Bali), Mahkamah Konstitusi mengeluarkan putusan yang retroaktif. Pertimbangan Mahkamah Konstitusi dalam putusannya, agar bisa memberikan keadilan substansif. $^{23}$

Kedua, argumentasi tersebut juga terbantahkan dengan sifat kekuatan mengikat Putusan Mahkamah Konstitusi yang memperoleh kekuatan hukum tetap sejak selesai diucapkan dalam sidang pleno terbuka untuk umum. Hal ini sebagaimana tertuang pada Pasal 47 UU No. 24 Tahun 2003 tentang Mahkamah Konstitusi sebagaimana telah diubah dengan UU No. 8 Tahun $2011^{24}$. Atas dasar itu, maka telah terjadi kesesatan berfikir ketika Putusan Mahkamah Konstitusi No. 30/PUU-XVI/2018 dipandang baru akan berlaku untuk pemilu 2024. Padahal sesuai dengan ketentuan Pasal 47 UU MK, maka Putusan Mahkamah Konstitusi

Tahun 2018 Tentang Pencalonan Perseorangan Peserta Pemilu anggota Dewan Perwakilan Daerah, tetap mempunyai kekuatan hukum mengikat dan berlaku umum sepanjang tidak diberlakukan surut terhadap Peserta Pemilu Anggota Dewan Perwakilan Daerah Tahun 2019 yang telah mengikuti Tahapan, Program dan Jadwal Penyelenggaraan Pemilihan Umum Tahun 2019 berdasarkan Peraturan KPU Nomor 7 tahun 2017. Lihat pada Putusan Mahkamah Agung Nomor $65 \mathrm{P} / \mathrm{HUM} / 2018 \mathrm{hlm}, 47$

${ }^{22}$ Putusan Mahkamah Konstitusi No. 102/PUU-VII/2009, yang dikeluarkan pada tanggal 6 Juli 2009 tepat dua hari sebelum waktu pencoblosan Pilpres 2009 (8 Juli 200).

${ }^{23}$ Ibid, Wiwin Suwandi, "OSO yang Jumawa; Peta Jalanan Untuk KPU”.

${ }^{24}$ Pasal 47 UU No. 24 Tahun 2003 yang menyatakan : "Putusan Mahkamah Konstitusi memperoleh kekuatan hukum tetap sejak selesai diucapkan dalam sidang pleno terbuka untuk uтum." 
yang diucapkan pada tanggal 23 Juli 2018 tersebut mulai berlaku pada hari itu itu juga dan telah berkekuatan hukum tetap. ${ }^{25}$

Ketiga, ditinjau dari kewenangan menguji Mahkamah Konstitusi. Jika didasarkan pada gagasan stufenbau theory yang eksponennya oleh Hans Kelsen, maka sepatutnya putusan Mahkamah Konstitusi yang diikuti. Sebab kewenangan menguji Mahkamah Konstitusi adalah Undang-Undang terhadap UUD 1945, sementara kewenangan menguji Mahkamah Agung adalah peraturan di bawah undang-undang terhadap undang-undang. Sehingga jelas demarkasi kewenangan judicial reviewe antara Mahkamah Konstitusi dengan Mahkamah Agung, yaitu judicial review yang dilakukan di Mahkamah Konstitusi adalah terkait adanya kerugian konstitusional yang dialami warga negara akibat berlakunya undangundang (constitutional rights). Sedangkan judicial riview di Mahkamah Agung, meliputi pihak yang merasa hak-hak hukumnya dirugikan oleh berlakunya peraturan perundang-undangan dibawah undang-undang (legal rights).

Konstitusi sebagai hukum tertinggi dan Mahkamah Konstitusi berwenang menguji keabsahan norma dalam UU yang bertentangan dengan UUD 1945 dengan putusan yang bersifat final and binding artinya tidak dapat diganggu gugat. Maka dari itu, putusan yang dikeluarkan oleh Mahkamah Konstitusi, setara dengan undang-undang. Namun justru terjadi kekeliruan sekaligus indikasi adanya pelanggaran terhadap asas erga omnes dalam putusan Mahkamah Konstitusi oleh PTUN dengan membatalkan Keputusan KPU No. 1130/PL.01bag.4-Kpt/06/KPU/IX/2018 yang roh dari keputusan ini bersandar pada Putusan Mahkamah Konstitusi No. 30/PUU-XVI/2018 tentang PUU Pasal 182 UU No. 7 Tahun 2017. Artinya, secara jenjang norma, Keputusan KPU a quo merujuk pada Putusan Mahkamah Konstitusi, sehingga meskipun berupa KTUN,

\footnotetext{
${ }^{25}$ Dalam beberapa perkara juducial review, suatu norma yang telah diuji oleh Mahkamah Konstitusi secara otomatis akan langsung mengikat dan harus ditafsirkan sesuai dengan Putusan Mahkamah Konstitusi tanpa harus ada perubahan terhadap undang-undang tersebut guna melaksanakan putusan Mahkamah Konstitusi. Sebagai contoh pengujian UU No. 22 Tahun 2001 yang berdasarkan tafsir Mahkamah Konstitusi harus ada campur tangan pemerintah dalam kebijakan penentuan harga BBM dan Gas Bumi. Tafsir Mahkamah Konstitusi tersebut tetap berlaku meskipun hingga saat ini belum ada revisi terhadap UU Migas.Lihat pada Muhammad Yahdi Salampessyí, "Babak Baru Konflik OSO dan KPU”, diakses pada hari Sabtu, 2 Maret 2019, pukul 15:20 WITA.
} 
Jurnal Al-Adalah :Jurnal Hukum dan Politik Islam

Vol. 5 No. 1, Januari 2020:52-69

P-ISSN :2406-8802- E-ISSN : 2685-550X

E-mail : aladalah@iain-bone.ac.id

http : /Jurnal.iain-bone.ac.id/index.php/aladalah

tapi keputusan tersebut tidak berdiri sendiri, jadi ketika PTUN membatalkan keputusan KPU tersebut, maka secara langsung menolak atau melawan putusan Mahkamah Konstitusi.

Berdasarkan pada argumentasi teoritis dan praktis sebagaimana telah diuraikan di atas, menunjukkan bahwa Putusan Mahkamah Konstitusi No. 30/PUU-XVI/2018 merupakan salah satu upaya untuk mengembalikan marwah dan independensi DPD dari hasrat partai politik untuk mengokupasi DPD, serta merupakan langkah progresif dalam mencegah terciptanya Oligarki Kekuasaan yang dibangun oleh elit Partai Politik di ranah DPD, sehingga Putusan Mahkamah Konstitusi wajib untuk dipatuhi dan dilaksanakan tanpa memandang waktu berlakunya.

\section{Penutup}

Berdasarkan pada eplikasi pada kajian dan pembahasan a qou, dapat disimpulkan bahwa konstitusionalitas pencalonan anggota DPD yang berasal dari partai politik merupakan konsep yang tidak dapat dibenarkan dan dapat dimaknai sebagai bagian dari hasrat partai politik untuk mengokupasi DPD secara sistematis dan masif, dengan argumentasi sebagai berikut; (i) Original Intent, pembentukan DPD pada awalnya untuk mengakomodir kepentingan daerah sehingga apapun alasannya, DPD tetap merupakan regional representation. Maka dari itu DPD harus benar-benar murni perseorangan, bukan dari partai politik; (ii) Komposisi konsep bicameralism yang mana harus ada perbedaan ingredients antara DPR dan DPD. Ketika DPR sudah mencakup partai politik, maka DPD adalah penyeimbangnya dengan cakupan daerah. Selain untuk mempertegas hakikat keberadaan mereka dalam lingkup lembaga perwakilan dengan konsep dua kamar, hal tersebut juga dapat menghindarkan kedua lembaga dari double representation dan hegemoni kekuasaan. (iii) Putusan Mahkamah Konstitusi No. 30/PUUXVI/2018 merupakan langkah progresif dalam mengembalikan marwah DPD, yang selama ini mulai di okupasi oleh partai politik. Dari urain kesimpulan tersebut, penulis merekomendasikan kepada anggota DPD, partai politik, dan pengkaji hukum, agar tidak melupakan original intent pembentukan DPD sebagai regional interpretation dalam balutan sistem parlemen dua kamar (bicameralism). 
Begitupula kepada Presiden dan DPR, dengan merujuk pada putusan Mahkamah Konstitusi yang bersifat final and binding, maka Putusan Mahkamah Konstitusi No. 30/PUU-XVI/2018 harus ditindaklanjuti dengan merubah pasal syarat pencalonan anggota DPD dalam Undang-Undang Pemilihan Umum, menjelang Pemilu 2024 yang akan datang.

\section{Daftar Pustaka}

\section{Buku dan Artikel Ilmiah}

Asshiddiqie, Jimly, 2017, Konstitusi dan Konstitusioanlisme Indonesia, Sinar Grafika, Jakarta Timur.

Arifin, Muhammad Zainul. "Suatu Pandangan Tentang Eksistensi Dan Penguatan Dewan Perwakilan Daerah." Jurnal Thengkyang Vol.1, No. 1 (2019): 115

Aris, Ismail, Irfan Amir, dan Septian Amrianto. 2019. "Konstitusionalitas Hak Angket Dewan Perwakilan Rakyat (Dpr) Terhadap Komisi Pemberantasan Korupsi (Kpk)." Al-Adalah: Jurnal Hukum dan Politik Islam 4 (2): 135-58. https://doi.org/10.35673/ajmpi.v4i2.436.

Marsuki, Masnur "Analisis Kontestasi Kelembagaan DPD Dan Upaya Mengefektifkan Keberadaannya", Jurnal Ilmu Hukum Vol. 15 No. 1, Januari 2008).

Nawawi, Jumriani, Irfan Amir, dan Muljan. 2019. "Problematika gagasan larangan mantan napi korupsi menjadi calon anggota legislatif." Al-Adalah: Jurnal Hukum dan Politik Islam 3 (2). Program Studi Hukum Tata Negara, Fakultas Syariah dan Hukum Islam IAIN Bone: 141-55.

Suryawan, Putu Wawan dan I Ketut Rai Setiabudhi, "Sah Tidaknya Anggota Dewan Perwakilan Daerah Masuk Partai Politik", Program Kekhususan Hukum Tata Negara, Fakultas Hukum, Universitas Udayana, https://ojs.unud.ac.id/index.php/Kerthanegara/article/view/40620, diakses pada hari Jumat, 15 Februari 2019, Pukul 17.20 WITA.

\section{Internet}

KoranJakarta.com, Jabatan Pimpinan DPD Tetap 5 Tahun, sumber: http://www.koran-jakarta.com/jabatan-pimpinan-dpd-tetap-5-tahun/, diak ses pada tanggal 4 Maret 2019, Pukul 18.33 WITA.

Nurcholis, Ahmad, Katastrofi Dewan Perwakilan Daerah : Parpolisasi, Korupsi dan Kemelut Konflik, Sumber https://ipc.or.id/katastrofi-dewanperwakilan-daerah-parpolisasi-korupsi-dan-kemelut-konflik/.

Suwandi, Wiwin, "OSO yang Jumawa; Peta Jalanan Untuk KPU" sumber : https://www.negarahukum.com/hukum/oesman-sapta-odang.html, diakses pada tanggal hari Sabtu, 2 Maret 2019, pukul 10:34 WITA.

\section{Peraturan Perundang-Undangan}


Undang-Undang No. 7 Tahun 2017 Tentang Pemilihan Umum (Lembaran Negara Republik Indonesia Tahun 2017 Nomor 182, Tambahan Lembaran Negam Republik Indonesia Nomor 6109)

Undang-Undang No. 12 Tahun 2003 Tentang Pemilihan Umum Anggota DPR, DPD dan DPRD (Lembaran Negara Republik Indonesia Tahun 2003 Nomor 37, Tambahan Lembaran Negara Republik Indonesia Nomor 4277)

Putusan Mahkamah Konstitusi Nomor 30/PUU-XVI/2018 tentang Pengujian Undang-Undang No. 7 Tahun 2017 tentang Pemilihan Umum terhadap UUD NRI 1945

Putusan Mahkamah Agung Nomor 65 P/HUM/2018.

PKPU No. 26 Tahun 2018 tentang Perubahan Kedua atas PKPU No. 14 Tahun 2018 tentang Pencalonan Perseorangan Peserta Pemilihan Umum Anggota DPD

Keputusan KPU No. 1130/PL.01bag.4-Kpt/06/KPU/IX/2018 tentang penetapan Daftar Calon Perseorangan Peserta Pemilihan Anggota DPD Tahun 2019 